\title{
Non-uniform radiation-induced biological responses at the tissue level involved in the health risk of environmental radiation: a radiobiological hypothesis
}

\author{
Hisanori Fukunaga* (D) and Kevin M. Prise(D)
}

\begin{abstract}
Background: The conventional concept of radiation protection is based on epidemiological studies of radiation that support a positive correlation between dose and response. However, there is a remarkable difference in biological responses at the tissue level, depending on whether radiation is delivered as a uniform or non-uniform spatiotemporal distribution due to tissue sparing effects (TSE). From the point of view of radiation micro-dosimetry, environmental radiation is delivered as a non-uniform distribution, and radiation-induced biological responses at the tissue level, such as TSE, would be implicated in individual risk following exposure to environmental radiation.
\end{abstract}

Hypothesis: We hypothesize that the health risks of non-uniform radiation exposure are lower than the same dose at a uniform exposure, due to TSE following irradiation. Testing the hypothesis requires both radiobiological studies using high-precision microbeams and the epidemiological data of environmental radiation-induced effects. The implications of the hypothesis will lead to more personalized approaches in the field of environmental radiation protection.

Conclusion: The detection of spatiotemporal dose distribution could be of scientific importance for more accurate individual risk assessment of exposure to environmental radiation. Further radiobiological studies on non-uniform radiation-induced biological responses at the tissue level are expected.

Keywords: Environmental radiation, Radiation-induced biological effects, Tissue sparing effects, Health risk assessment, Radiological protection

\section{Background}

Radiation-induced effects on biological tissues were recognized immediately after the pivotal discovery of X-rays by Wilhelm Röntgen in 1895 [1]. The first radiation-related solid cancer was reported in 1902, arising in an ulcerated area of the skin, and, as reported in 1911, leukemia was diagnosed in five radiation workers [2]. According to the results of previous epidemiological studies, including the Life Span Study (LSS) of Japanese atomic bomb survivors, these biological effects seem to be dose-dependent with or without a threshold [3-6], thus the current concept of radiological protection is based on the dose-response model. In fact, for more

* Correspondence: hfukunaga01@qub.ac.u

Centre for Cancer Research and Cell Biology, Queen's University Belfast, 97 Lisburn Road, Belfast BT9 7AE, UK than four decades, according to reports and statements of radiation research organizations, such as the US National Council on Radiation Protection and Measurements (NCRP) and the International Commission on Radiological Protection (ICRP), a linear non-threshold (LNT) model has been used for radiological protection purposes [7, 8]. In May 2018, NCRP published the Commentary No. 27, which supports the LNT model for radiological protection, based on recent results of epidemiological studies of radiation [9], although there are technical limitations to epidemiology, such as study design, sample size and confounding factors. Thus, the risk assessment of environmental radiation exposure is still based on the LNT model, although quantifying the risk still remains problematic and subject to uncertainty [10]. 
From the perspective of recent radiobiology, we highlight a specific challenge: the contribution of spatiotemporal dose distribution might be underestimated in the field of radiological protection. In an epidemiological cohort study of radiation, the researchers collected the data of the total radiation dose each participant was exposed to; however, it is technically difficult to have a clear grasp of their accurate irradiation situations, such as radiation dose rates or spatial distributions in the whole body. This is one of the possible technical limitations of the current epidemiological approach to radiation.

The quantity and quality of DNA damage is determined by the radiation type and dose [11]. For instance, high and low linear-energy-transfer (LET) radiations induce different spectra and qualities/complexity of DNA lesions, due to the differences in radiation track structures [12]. This also impacts on the dose per cell delivered by individual tracks at low doses which will be radiation quality dependent. Specifically, as shown in Fig. 1, from the point of view of radiation microdosimetry, for low-dose exposure, such as from environmental radiation, or low-dose rates of radiation, the energy deposition of radiation is localized along its track, resulting in a non-uniform distribution of exposed or unexposed cells in irradiated tissue [13, 14]. Thus, for environmental radiation, there are possible interactions between the irradiated and the non-irradiated cells and the dynamics of these cells in the tissue involved in radiation-induced biological responses at the wholetissue level [15]. In fact, it is well known that cells that do not receive radiation doses directly but receive signals from nearby or neighboring irradiated cells behave as though they have been exposed [16, 17]. These welldocumented responses are collectively known as nontargeted effects, although the underlying molecular mechanisms are not completely understood [18]. However, the conventional concept of radiological protection has not taken into consideration such tissue-level responses following exposure to environmental radiation.

In clinical practice, the tissue-sparing response in non-uniform radiation fields was recognized more than one century ago. In 1909, Alban Köhler reported the first clinical observation of a tissue-sparing response during grid radiotherapy in which spatially fractionated radiation was delivered using a grid-like pattern of beams [19]. In 1995, a notable tissue-sparing was reported in rat brain tissues during a microbeam radiation therapy (MRT) study [20], performed at the National Synchrotron Light Source, Brookhaven National Laboratory. Since then, the tissue-sparing effect (TSE) of MRT, which is based on a spatial fractionation of synchrotrongenerated X-ray microbeams at the microscale level, has been confirmed in a large variety of species and tissue types, although the underlying mechanism of TSE remains to be established [19-25]. The TSE of spatialfractionated radiation indicates significant implications not only for clinical applications, but also for the improvement of risk assessment of exposure to nonuniform radiation, such as environmental radiation. For a more accurate risk assessment of exposure to

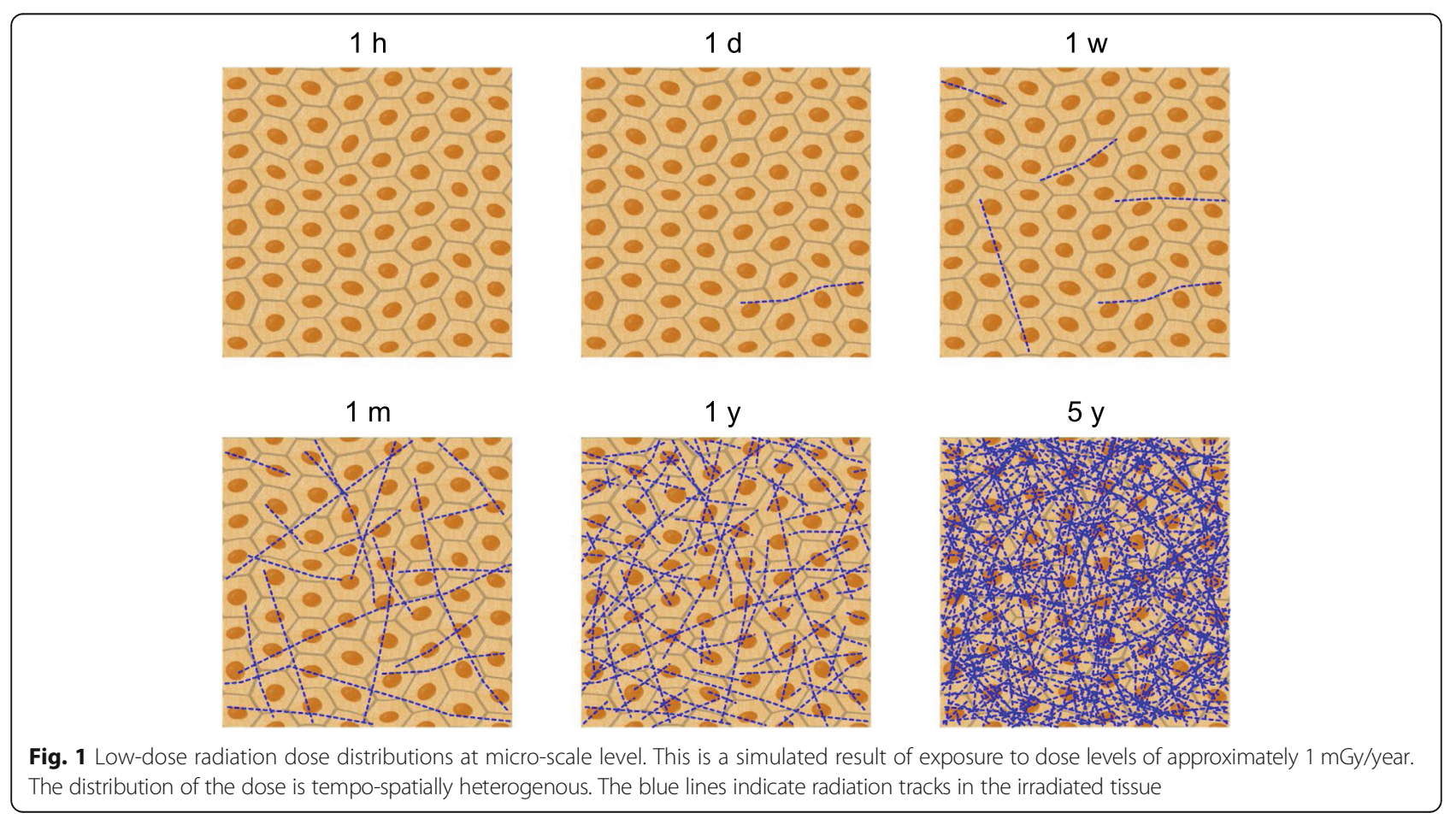


environmental radiation, the assessment of the spatiotemporal dose distribution could be of scientific importance due to the TSE.

\section{Presentation of the hypothesis}

As shown in Fig. 2, intercellular responses, such as apoptosis and clearance of apoptotic cells, cell competition and tissue repair/regeneration, would be involved in TSE in response to non-uniform radiation fields. Depending on the efficiency of acute cellular responses following irradiation, the damaged cells either survive or are removed from the tissue. In general, if radiationinduced damages of cellular components, in particular DNA, are not repaired sufficiently, the damaged cells will commit suicide in a process called apoptosis, which is a clearance system in multicellular organisms [26, 27]. Further, for tissue homeostasis, cell competition is essential as a cell fitness-sensing mechanism seen from insects to mammals that eliminates cells that, although viable, are less fit than their neighbors [28]. Damaged cells induced by non-uniform radiation would be removed by the neighboring cells due to cell competition, resulting in the prevention of a pathological state, such as carcinogenesis [29]. In addition, to remove cancer cells, interactions between the immune system and cancer governed by a complex network of biological pathways are a rapidly developing research area [30]. The therapeutic effects of radiotherapy have been observed not only in cancer cells, but also in their microenvironment. Today the role of the host's immune system in the mechanisms of tumor regression by generating a cytotoxic adaptive immune response is well described and is recognized as immunogenic cell death (ICD) [31]. In this complex myriad of events, intrinsic characteristics of the tumor cells (tumor type, immunogenic capacity) and the immune status of the host are important factors determining the successful induction of ICD [32]. In addition to the potential synergism in terms of local control, the possibility to obtain systemic responses, described initially by Mole in 1953 as "the abscopal effect [33]," mediated by ICD has stimulated great interest. After the complete clearance of damaged cells, tissue repair/regeneration generally occurs for the maintenance of normal tissue functions, namely homeostasis. Somatic stem cells migrate from the intact to the defective parts and regenerate the structure and function of tissue by their proliferation and differentiation $[34,35]$. Such tissue homeostasis mechanisms could be involved in radiation-induced biological responses at the tissue level. However little is know, particularly with respect to immune system modulation at low environmental doses.

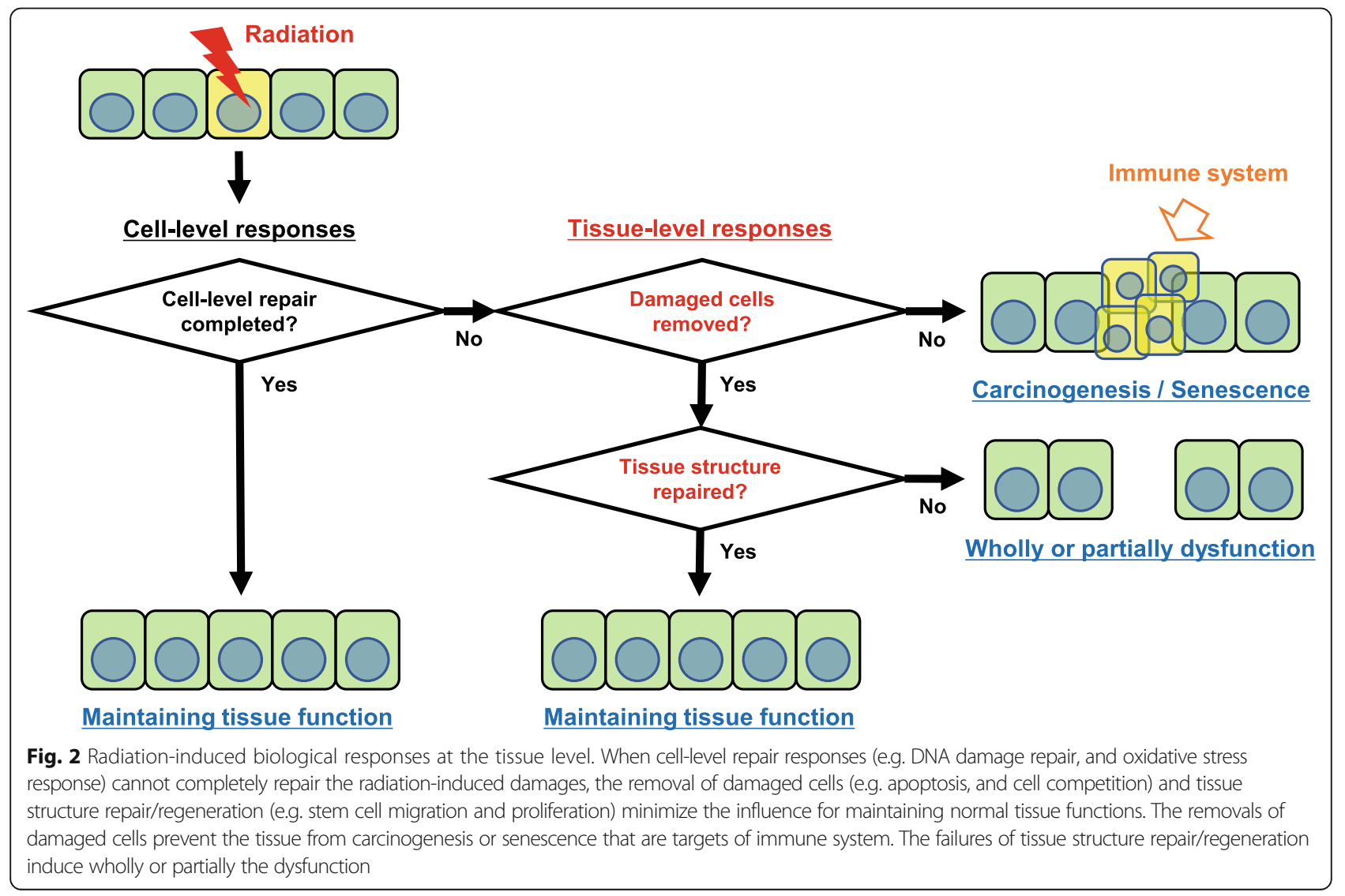


We do not intend to question the conventional LNT concept for radiological protection purposes. Our aim is to suggest further studies on the mechanisms of radiation-induced biological responses at the tissue level for a more accurate estimation of environmental radiation risk. We hypothesize that the health risks of environmental radiation exposure are prone to be overestimated because at the very least radiation-induced biological responses at the tissue level, especially TSE, are not adequately considered. Conventionally, animal studies have been commonly used to investigate the radiation-induced biological responses at the tissue level. However, most of these studies have been performed by uniform radiation exposure, such as total body irradiation, thus the knowledge on tissue homeostasis responses following exposure to non-uniform radiation, such as environmental radiation, appears to be insufficient even now.

\section{Testing the hypothesis}

Because the technology of MRT has only recently been developed, the molecular mechanisms of TSE in response to non-uniform radiation fields have not yet been fully determined. As we suggest in this paper, there appears to be several potential biological responses involved in tissue homeostasis after exposure to non-uniform radiation, such as environmental radiation. Given the use of high-precision microbeams, further radiobiological studies on such biological responses are foreseen. Key to this will be an appropriate assessment of the interrelationship between dose and its localization in tissue volumes.

Also, epidemiological studies of non-uniform radiationinduced biological effects will provide a more comprehensive radiological understanding of response mechanisms, leading to improved accuracy in the estimations of environmental radiation risk. The confirmation of spatiotemporal dose distribution of environmental radiation will be of scientific importance in such studies.

\section{Implications of the hypothesis}

The hypothesis will suggest reconsidering the concept of the health-risk assessment of environmental radiation from the viewpoint of precision medicine. If the evidence for the hypothesis can be strengthened by appropriate radiobiological and epidemiological studies, the target of current environmental radiation risk assessment approaches will show a dramatic change from the "average person" to "each person". To consider individual spatiotemporal exposure to radiation will provide a novel insight into individual risk assessment of environmental radiation. For the coming era of precision medicine, in addition to the consideration of genomic factors [36], the global scientific community, including such bodies as NCRP and ICRP, need to consider how to integrate similar personalized approaches into a future concepts of radiological protection. We hope that our hypothesis will stimulate scientific debate in the field.

Since the large-scale nuclear disasters in Chernobyl, in 1986, and in Fukushima, in 2011, there has been a great deal of public concern about the possible health effects of long-term and low-dose radiation exposure on current and future generations [37-39]. Previous data based on population cohorts, such as the LSS, estimate that the risk of cancer from radiation exposure will increase at doses exceeding approximately $100 \mathrm{mSv}[4,5]$, although there are technical limitations and biases [40]. These data, however, are mainly based on acute irradiation situations, such as the explosion of the atomic bomb, and could not take weighting factors of spatiotemporal dose distributions into consideration. The hypothesis we suggest would provide a novel approach for more accurate individual risk assessment of such low-dose and long-term environmental radiation exposures.

Risk assessment of exposure to environmental radiation is essential for human activity in space. As future missions explore beyond low-Earth orbit (LEO) and away from the protection of the Earth's magnetic shielding, the nature of radiation exposure that astronauts encounter will include higher radiation exposures [41]. During transit outside of LEO, every cell nucleus within an astronaut's body would be traversed by a proton or electron ray every few days, and by a heavier galactic cosmic ray ion (e.g., $\mathrm{O}, \mathrm{Si}, \mathrm{Fe}$ ) every few months [42]. For a more accurate risk assessment of exposure to such an environment, the understanding of non-uniform, radiation-induced biological responses at the tissue level will be of scientific importance.

\section{Abbreviations}

ICD: Immunogenic cell death; ICRP: International Commission on Radiological Protection; LEO: Low-Earth orbit; LET: Linear-energy-transfer; LNT: Liner nonthreshold; LSS: Life Span Study of Japanese atomic bomb survivors; MRT: Microbeam radiotherapy; NCRP: National Council on Radiation Protection and Measurements, USA; TSE: Tissue-sparing effects

\section{Funding}

There is no specific grant support to be disclosed.

Availability of data and materials

There are no restrictions on data availability.

\section{Authors' contributions}

H.F. and K.M.P. co-developed the concept of this manuscript. H.F. wrote the first draft manuscript. K.M.P. provided comments and amendments to the draft manuscript. Both authors read and approved the final manuscript.

Ethics approval and consent to participate Not applicable.

Competing interests

The authors declare that they have no competing interests. 


\section{Publisher's Note}

Springer Nature remains neutral with regard to jurisdictional claims in published maps and institutional affiliations.

Received: 23 June 2018 Accepted: 18 December 2018

Published online: 29 December 2018

\section{References}

1. Daniel J. THE X-RAYS. Science. 1896;3:562-3.

2. Shah DJ, Sachs RK, Wilson DJ. Radiation-induced cancer: a modern view. $\mathrm{Br}$ J Radiol. 2012;85:e1166-73.

3. Brenner DJ, Doll R, Goodhead DT, Hall EJ, Land CE, Little JB, et al. Cancer risks attributable to low doses of ionizing radiation: assessing what we really know. Proc Natl Acad Sci U S A. 2003;100:13761-6.

4. Richardson D, Sugiyama H, Nishi N, Sakata R, Shimizu Y, Grant EJ, et al. lonizing radiation and leukemia mortality among Japanese atomic bomb survivors, 1950-2000. Radiat Res. 2009;172:368-82.

5. Grant EJ, Brenner A, Sugiyama H, Sakata R, Sadakane A, Utada M, et al. Solid Cancer incidence among the life span study of atomic bomb survivors: 1958-2009. Radiat Res. 2017:187:513-37.

6. Ozasa K, Grant EJ, Kodama K. Japanese legacy cohorts: the life span study atomic bomb survivor cohort and survivors' offspring. J Epidemiol. 2018;28: $162-9$.

7. International Commission on Radiological Protection. The 2007 recommendations of the international commission on radiological protection. ICRP publication 103. Ann ICRP. 2007:37:1-332.

8. Boice JD. The linear nonthreshold (LNT) model as used in radiation protection: an NCRP update. Int J Radiat Biol. 2017;93:1079-92.

9. National Council on Radiation Protection and Measurements. Implications of recent epidemiologic studies for the linear nonthreshold model and radiation protection. NCRP commentary No. 27. Bethesda, MD: National Council on Radiation Protection and Measurements; 2018.

10. Mullenders $L$, Atkinson M, Paretzke H, Sabatier L, Bouffler S. Assessing cancer risks of low-dose radiation. Nat Rev Cancer. 2009;9:596-604

11. Averbeck D, Salomaa S, Bouffler S, Ottolenghi A, Smyth V, Sabatier L. Progress in low dose health risk research. Mutat Res Mutat Res. 2018; 776:46-69.

12. Goodhead DT. Initial events in the cellular effects of ionizing radiations: clustered damage in DNA. Int J Radiat Biol. 1994;65:7-17.

13. Booz J, Feinendegen LE. A microdosimetric understanding of low-dose radiation effects. Int J Radiat Biol Relat Stud Phys Chem Med. 1988;53:13-21.

14. Booz J, Braby L, Coyne J, Kliauga P, Lindborg L, Menzel H-G, et al. ICRU report 36: Microdosimetry. J Int Comm Radiat Units Meas. 1983;0s 19:1-119.

15. Prise KM, Folkard M, Michael BD. Bystander responses induced by low LET radiation. Oncogene. 2003;22:7043-9.

16. Prise KM, O'Sullivan JM. Radiation-induced bystander signalling in cancer therapy. Nat Rev Cancer. 2009;9:351-60.

17. Fukunaga H, Yokoya A, Taki Y, Prise KM. Radiobiological implications of Fukushima nuclear accident for personalized medical approach. Tohoku J Exp Med. 2017:242:77-81.

18. Burtt JJ, Thompson PA, Lafrenie RM. Non-targeted effects and radiationinduced carcinogenesis: a review. J Radiol Prot. 2016;36:R23-35.

19. Schültke E, Balosso J, Breslin T, Cavaletti G, Djonov V, Esteve F, et al. Microbeam radiation therapy - grid therapy and beyond: a clinical perspective. Br J Radiol. 2017;90:20170073.

20. Slatkin DN, Spanne P, Dilmanian FA, Gebbers JO, Laissue JA. Subacute neuropathological effects of microplanar beams of $x$-rays from a synchrotron wiggler. Proc Natl Acad Sci U S A. 1995;92:8783-7.

21. Laissue JA, Geiser G, Spanne PO, Dilmanian FA, Gebbers JO, Geiser M, et al. Neuropathology of ablation of rat gliosarcomas and contiguous brain tissues using a microplanar beam of synchrotron-wiggler-generated $\mathrm{X}$ rays. Int J Cancer. 1998;78:654-60.

22. Dilmanian FA, Zhong Z, Bacarian T, Benveniste $H$, Romanelli $P$, Wang $R$, et al. Interlaced $\mathrm{x}$-ray microplanar beams: a radiosurgery approach with clinical potential. Proc Natl Acad Sci U S A. 2006;103:9709-14.

23. van der Sanden B, Bräuer-Krisch E, Siegbahn EA, Ricard C, Vial J-C, Laissue J. Tolerance of arteries to microplanar $X$-ray beams. Int J Radiat Oncol Biol Phys. 2010;77:1545-52.

24. Bouchet A, Lemasson B, Christen T, Potez M, Rome C, Coquery N, et al. Synchrotron microbeam radiation therapy induces hypoxia in intracerebral gliosarcoma but not in the normal brain. Radiother Oncol. 2013;108:143-8.
25. Grotzer MA, Schültke E, Bräuer-Krisch E, Laissue JA. Microbeam radiation therapy: clinical perspectives. Phys Medica. 2015:31:564-7.

26. Galluzzi L, Vitale I, Aaronson SA, Abrams JM, Adam D, Agostinis P, et al. Molecular mechanisms of cell death: recommendations of the nomenclature committee on cell death 2018. Cell Death Differ. 2018;25:486-541.

27. Nagata S. Apoptosis and clearance of apoptotic cells. Annu Rev Immunol. 2018:36:489-517.

28. Di Gregorio A, Bowling S, Rodriguez TA. Cell competition and its role in the regulation of cell fitness from development to Cancer. Dev Cell. 2016;38: $621-34$.

29. Maruyama T, Fujita Y. Cell competition in mammals - novel homeostatic machinery for embryonic development and cancer prevention. Curr Opin Cell Biol. 2017:48:106-12.

30. Topalian SL, Taube JM, Anders RA, Pardoll DM. Mechanism-driven biomarkers to quide immune checkpoint blockade in cancer therapy. Nat Rev Cancer. 2016;16:275-87.

31. Chajon E, Castelli J, Marsiglia H, De Crevoisier R. The synergistic effect of radiotherapy and immunotherapy: a promising but not simple partnership. Crit Rev Oncol Hematol. 2017;111:124-32.

32. Apetoh L, Tesniere A, Ghiringhelli F, Kroemer G, Zitvogel L. Molecular interactions between dying tumor cells and the innate immune system determine the efficacy of conventional anticancer therapies. Cancer Res. 2008;68:4026-30.

33. Mole RH. Whole body irradiation—radiobiology or medicine? Br J Radiol. 1953;26:234-41.

34. Biteau B, Hochmuth CE, Jasper H. Maintaining tissue homeostasis: dynamic control of somatic stem cell activity. Cell Stem Cell. 2011;9:402-11.

35. Eming SA, Martin P, Tomic-Canic M. Wound repair and regeneration: mechanisms, signaling, and translation. Sci Transl Med. 2014;6:265sr6.

36. Fukunaga $\mathrm{H}$, Yokoya $\mathrm{A}$, Taki Y. Now is the time to consider personalized effective dose. Int J Radiat Oncol Biol Phys. 2016;96:479-80.

37. World Health Organization. Health risk assessment from the nuclear accident after the 2011 great East Japan earthquake and tsunami, based on a preliminary dose estimation. Geneva: WHO Press; 2013.

38. United Nations Scientific Committee on the Effects of Atomic Radiation Developments since the 2013 UNSCEAR report on the levels and effects of radiation exposure due to the nuclear accident following the great EastJapan earthquake and tsunami. New York, NY: United Nations; 2015.

39. Fukunaga H, Butterworth KT, Yokoya A, Ogawa T, Prise KM. Low-dose radiation-induced risk in spermatogenesis. Int J Radiat Biol. 2017;93:1291-8.

40. Stewart A. A-bomb data: detection of bias in the life span study cohort. Environ Health Perspect. 1997;105 (Suppl 6):1519-21.

41. Chancellor JC, Blue RS, Cengel KA, Auñón-Chancellor SM, Rubins KH, Katzgraber $\mathrm{HG}$, et al. Limitations in predicting the space radiation health risk for exploration astronauts. NPJ Microgravity. 2018;4:8.

42. Cucinotta FA, Durante M. Cancer risk from exposure to galactic cosmic rays: implications for space exploration by human beings. Lancet Oncol. 2006;7: $431-5$.

Ready to submit your research? Choose BMC and benefit from:

- fast, convenient online submission

- thorough peer review by experienced researchers in your field

- rapid publication on acceptance

- support for research data, including large and complex data types

- gold Open Access which fosters wider collaboration and increased citations

- maximum visibility for your research: over $100 \mathrm{M}$ website views per year

At BMC, research is always in progress.

Learn more biomedcentral.com/submissions 